\title{
Arouse the Creativity of a Generation of Millenial Doctrines with the Media Learning Physics and Innovative Eco-Friendly
}

\author{
Nurhidayati ${ }^{1}$, Syifa Fauzia ${ }^{2}$, Al Lu'lu Ul Maknun ${ }^{3}$ \\ ${ }^{1}$ Physics Education, ${ }^{2}$ Physics, ${ }^{3}$ Chemical Education, Faculty of Science and Technology, UIN Sunan Kalijaga \\ Jl. Marsda Adisucipto No 1 Yogyakarta 55281, Indonesia. Tel. + 62-274-540971, Fax. + 62-274-519739 \\ ${ }^{1}$ Email: nur99656@gmail.com
}

\begin{abstract}
Learning media is an auxiliary tool effectively which can be used by teachers to achieve the desired goals. Learning media usage in the process of teaching and learning can evoke desire and renewed interest, evoking motivation and stimulation of learning activities, even bringing the influences of Psychology against the students. Learning Media research already done by observing the learning achievements before and after using the media. On the research of Alamsyah Noerseelha with the title of "research learning media use power point" in SMK N 1 learning achievements acquired Sumedang of 68.57 before using media and 80.00 after using media. With the name and title of the same study at Junior High School N 1 Cimanggung obtained amounted to 61.90 before using media and 80.95 after using media. and in Junior High School N 1 Pamulihan of 67.74 before using media and 83.33 after using media. The main factors that can enhance the learning achievements and arouse the creativity of learners, namely the media and education. While the hallmark of a generation of millennial doctrines which tend to be deeply affected by the technology make it quickly bored with the monotonous thing. To address the authors offer solutions in the form of ideas where teachers use the media learning and learners practice to create a new media that he apply the learning of physics that they already get in College. Because of a growing country is the question "want to be tomorrow what?" while the question of an advanced country that "tomorrow would like for what?". The aim to arouse the creativity of a generation of millennial doctrines created new things by making it interested in the learning media that already exists.
\end{abstract}

Keywords: Creating, Media learning, The generation of millennial doctrines

\section{INTRODUCTION}

Government Regulation No. 19 of 2005 concerning National Education Standards. Article 42 paragraph 1 of PP No. 19 of 2005 states that "Every education unit must have facilities that include furniture, educational equipment, educational media, books and other learning resources, consumables, and other equipment needed to support an orderly learning process and sustainable ". This regulation shows how important facilities and infrastructure are in learning activities, one example is learning media.

Learning media is an effective tool that can be used by teachers to achieve the desired goals. Good physics learning must link Physics to everyday life. Physics is not just learning mathematics, even though the process of mathematics is very necessary in physics. Physics teachers tend to feel they have taught the concept of physics if they have made mathematical formulations for the concepts they teach. Physics is different from mathematics because physics explains the fundamental relationship between the amount of physics, while mathematics strictly aims to get the consequences of basic assumptions. Another weakness of physics learning is that educators tend to display natural science products in the form of complex physical formulas that make students dislike physics which ultimately has difficulty understanding the concept and misconceptions (Fitri et. Al, 2018). The use of instructional media in the teaching and learning process can generate new desires and interests, generate motivation and stimulation of learning activities, and even bring psychological influences on students.

Ideally, learning must also adapt to the times. Students who generally enter the millennial generation today are not the same as students in the previous era. The previous generation was famous for its characteristics: able to adapt, be able to accept change well, and referred to as a formidable generation, independent, loyal, highly prioritizing image, fame, and money, as well as hardworking types (Jurkiewicz, 2000). Unlike the current millennial generation, which grew in the booming internet era. This generation uses a lot of instant technology, such as e-mail, SMS, instant messaging, and social media such as Facebook and Twitter (Lyons, 2004). Characteristics formed in millennial generations are internet addiction, confidence, high self-esteem, more openness, and tolerance for change (Kilber et. Al, 2014).

However, behind the characters that tend to be instantaneous and technology addicted, the generation that is mentioned as the strawberry generation has the potential to be developed. The use of very high social media actually facilitates access to information, so that it can get teaching through various sources. Research conducted by Poppy Panjaitan and Arik Prasetya (2017) shows that social media has a significant and positive influence on work productivity. If applied to students in learning activities it will give a positive influence, of course with the supervision of the teacher. The main factors that can improve learning achievement and raise students' creativity are media 
and education. So far, the majority of physics instructors are solely verbal communication through the telling of words so that students get bored quickly and the characteristics of Millennial generations that tend to be very influenced by technology make it quickly bored with monotonous things. The ease of access to information can be used as a learning tool. In this case, not only teachers can make learning media, but students/students themselves are able to make their own learning media by applying the knowledge gained and with the help of information from various sources.
Thus, students will be motivated to learn independently, creatively, and innovatively, and productively.

According to Kupperschmidt's (2000) generation is a group of individuals who identify his group based on similarity of year of birth, age, location, and events events in the lives of a group of individuals who have significant influence in their growth phase. Some opinions about the difference generation can be seen in the following table:

Table 1. The grouping of generations

\begin{tabular}{|c|c|c|c|c|c|}
\hline Source & Label & & & & \\
\hline Tapscott (1998) & & $\begin{array}{l}\text { Baby Boom Generation } \\
(1946-1964)\end{array}$ & $\begin{array}{l}\text { Generation X } \\
(1965-1975)\end{array}$ & $\begin{array}{l}\text { Digital Generation } \\
(1976-2000)\end{array}$ & \\
\hline Howe \& Strauss (2000) & $\begin{array}{l}\text { Silent Generation } \\
(1925-1943)\end{array}$ & $\begin{array}{l}\text { Boom Generation } \\
(1943-1960)\end{array}$ & $\begin{array}{l}\text { 13th Generation } \\
(1961-1981)\end{array}$ & $\begin{array}{l}\text { Millenial Generation } \\
(1982-2000)\end{array}$ & \\
\hline Zemke et al (2000) & $\begin{array}{l}\text { Veterans } \\
(1922-1943)\end{array}$ & $\begin{array}{l}\text { Baby Boomers } \\
(1943-1960)\end{array}$ & $\begin{array}{l}\text { Gen-X ers } \\
(1960-1980)\end{array}$ & $\begin{array}{l}\text { Nexters } \\
(1980-1999)\end{array}$ & \\
\hline $\begin{array}{l}\text { Lancaster \& Stillman } \\
\text { (2002) }\end{array}$ & $\begin{array}{l}\text { Traditionalist } \\
(1900-1945)\end{array}$ & $\begin{array}{l}\text { Baby Boomers } \\
(1946-1964)\end{array}$ & $\begin{array}{l}\text { Generation Xers } \\
(1965-1980)\end{array}$ & $\begin{array}{l}\text { Generation Y } \\
(1981-1999)\end{array}$ & \\
\hline Martin \& Tulgan (2002) & $\begin{array}{l}\text { Silent Generation } \\
(1925-1945)\end{array}$ & $\begin{array}{l}\text { Baby Boomers } \\
(1946-1964)\end{array}$ & $\begin{array}{l}\text { Generation X } \\
(1965-1977)\end{array}$ & $\begin{array}{l}\text { Millenials } \\
(1978-2000)\end{array}$ & \\
\hline $\begin{array}{l}\text { Oblinger \& Oblinger } \\
(2005)\end{array}$ & Matures (<1946) & $\begin{array}{l}\text { Baby Boomers } \\
(1947-1064)\end{array}$ & $\begin{array}{l}\text { Generation Xers } \\
(1965-1980)\end{array}$ & $\begin{array}{l}\text { Gen-Y/NetGen } \\
(1981-1995)\end{array}$ & $\begin{array}{l}\text { Post Millenials } \\
\text { (1995-present) }\end{array}$ \\
\hline
\end{tabular}

Generation $\mathrm{Y}$ is known as the generation of millennial doctrines or the Millennium. The phrase Generation Y begins to wear on the big United States newspaper editorial in August 1993. The characteristics of generation $\mathrm{Y}$ are: the characteristics of each individual is different, depending on where he grew up, economic, and social strata of his family, a very open communication pattern than previous generations, social media users Bigot and his life was deeply affected by technological developments, more open political and economic views, so they look very reactive to changes in the environment that occur around him, have the attention more on wealth (Lyons, 2004). Research results from Bencsik \& Machova (2016) show the difference in the characteristics of the generation, the results can be seen in the following table

Table 2. Generational behavioural characteristics of different age-groups.

\begin{tabular}{|c|c|c|c|c|}
\hline Factors & Baby - boom & $\mathrm{X}$ generation & Y generation & $\mathrm{Z}$ generation \\
\hline View & $\begin{array}{l}\text { Communal, unified } \\
\text { thinking }\end{array}$ & $\begin{array}{l}\text { Self-centred and medium- } \\
\text { term }\end{array}$ & Egotistical, short term & $\begin{array}{l}\text { No sense of commitment, be happy } \\
\text { with what you have and live for the } \\
\text { present }\end{array}$ \\
\hline Relationship & $\begin{array}{l}\text { First and fore most } \\
\text { personal }\end{array}$ & $\begin{array}{l}\text { Personal and virtual } \\
\text { networks }\end{array}$ & Principally virtual, network & Virtual and superficial \\
\hline Aim & Solid existence & $\begin{array}{l}\text { Multi-environment, } \\
\text { secureposition }\end{array}$ & Rivalry for leader Position & Live for the present \\
\hline Self realization & $\begin{array}{l}\text { Conscious carrier } \\
\text { building }\end{array}$ & Rapid promotion & Immediate & Questions the need for it at all \\
\hline IT & $\begin{array}{l}\text { It is based on self- } \\
\text { instruction\& incomplete }\end{array}$ & Uses with confi dence & Part of its every day life & Intuitive \\
\hline Values & $\begin{array}{l}\text { Patience, softskills, } \\
\text { respect for traditions, EQ, } \\
\text { hard work }\end{array}$ & $\begin{array}{l}\text { Hard work, openness, } \\
\text { respect for diversity, } \\
\text { curiosity, practicality }\end{array}$ & $\begin{array}{l}\text { Flexibility, mobility, broad but } \\
\text { superficial knowledge, succes } \\
\text { sorientation, creativity, freedom of } \\
\text { information takes priority }\end{array}$ & $\begin{array}{l}\text { Live for the present, rapid reaction to } \\
\text { everything, initiator, } \\
\text { brave, rapid information access and } \\
\text { content search }\end{array}$ \\
\hline $\begin{array}{l}\text { Other possible } \\
\text { characteristics }\end{array}$ & $\begin{array}{l}\text { Respect for hierarchy, } \\
\text { exaggerated modesty or } \\
\text { arrogant inflexibility, } \\
\text { passivity, cynicism, } \\
\text { disappointment }\end{array}$ & $\begin{array}{l}\text { Rule abiding, materialistic, } \\
\text { fair play, less respect for } \\
\text { hierarchy, has a sense of } \\
\text { relativity, need to prove } \\
\text { themselves }\end{array}$ & $\begin{array}{l}\text { Desire for independence, no respect } \\
\text { for tradition, quest for new forms of } \\
\text { knowledge, inverse socialization, } \\
\text { arrogant, } \\
\text { home office and part-time work, } \\
\text { interim management, undervalue } \\
\text { soft skills and EQ }\end{array}$ & $\begin{array}{l}\text { Differing view points, lack of } \\
\text { thinking, happiness, pleasure, } \\
\text { divided attention, lack of conse } \\
\text { quential thinking, no desire to make } \\
\text { sense of things, the boundaries of } \\
\text { work and enter } \\
\text { tainment overlap, feel at home } \\
\text { anywhere }\end{array}$ \\
\hline
\end{tabular}


In Munadi (2012:7) States that any form of learning requires means/support tools that can facilitate learning activities, one of which is the medium of instruction.

A good IPA learning must relate the IPA with the everyday lives of students. Students are given the opportunity to ask questions, generate ideas, build up curiosity about everything in their environment, build the necessary skills, and raises awareness that learning the IPA became particularly required to be studied. The use of learning media will reproduce the learning experience of students, make students become bored, and provides an attractive learning to students (De Vito in Samatowa, 2011). Methods of teaching will be more varied, not merely verbal communication through the utterance of words by teachers, so students do not get tired of teaching and not run out of steam, especially if the teacher teaches at any hour lesson. Students may be doing more learning activities, for not only listening to descriptions of teachers, but also other activities such as observing, perform, demonstrate, playing, and others (Sudjana \& Rivai, 2011:2).

Rohman (2013:161) suggests that the use of the learning media in the process of teaching and learning can evoke desire and renewed interest, evoking motivation and stimulation of learning activities, even bringing psychology towards influences students.

Table 3. A variety of instructional media research results.

\begin{tabular}{|c|c|c|c|c|}
\hline \multirow[b]{2}{*}{ Name } & \multirow[b]{2}{*}{ Title Research } & \multirow[b]{2}{*}{ Location } & \multicolumn{2}{|c|}{ Learning Achievement Score } \\
\hline & & & $\begin{array}{l}\text { Before Using } \\
\text { Media }\end{array}$ & $\begin{array}{l}\text { After Using } \\
\text { Media }\end{array}$ \\
\hline \multirow[t]{4}{*}{ Alamsyah Noerseelha } & Research Learning Media Using Power Point & SMKN 1 Sumedang & 68,57 & 80,00 \\
\hline & & SMPN 1 Cimanggung & 61,90 & 80,95 \\
\hline & & SMPN 1 Pamulihan & 67,74 & 83,33 \\
\hline & & SMPN 1 Tanjungsari & 36,11 & 83,33 \\
\hline Fahrida Estiningrum & $\begin{array}{l}\text { The effectivity of using picture media in } \\
\text { increasing numeracy mathematics } 1 \text { st grade } \\
\text { students at SDN Pringtulis } 2\end{array}$ & SD N 2 Pringtulis Jepara & 60,60 & 80,49 \\
\hline Yulinda Karimah & $\begin{array}{l}\text { Improving the skill of listening to children's } \\
\text { stories through audio visual animation media } \\
\text { for } 6 \text { th grade students of SDI } 1 \text { Ma'had Islam, } \\
\text { Pekalongan }\end{array}$ & $\begin{array}{l}\text { SDI } 1 \text { Ma'had Islam, } \\
\text { Pekalongan }\end{array}$ & 54,40 & 84,20 \\
\hline $\begin{array}{l}\text { Lusia Riyati } \\
\text { Maningrum }\end{array}$ & $\begin{array}{l}\text { The effectiveness of the application of the } \\
\text { standard approach to learning sub subject } \\
\text { matter around and the circle area in the 8th } \\
\text { grade students of SMP Pangudi Luhur } \\
\text { Giriwoyo Wonogiri }\end{array}$ & $\begin{array}{l}\text { SMP Pangudi Luhur } \\
\text { Giriwoyo Wonogiri }\end{array}$ & 74,83 & 85,50 \\
\hline
\end{tabular}

\section{Mobile Projector}

Mobile Projector is a simple imitation of the Projector in the form of a different and more innovative, namely cardboard shoes are made to resemble the Projector with the help of a magnifying glass (lup) to see clearer and larger than the size of the picture or the actual video. Also with the help of Rotation Control in mobile applications that can be downloaded at Play Store to set the rotation of the image or video when faced with a magnifying glass and formed a shadow rising, real and enlarged.

It can provide a new alternative of Projector, ranging from the simple ingredients, easy to find, a sturdy shoe boxes and can be designed as you wish, you can take them everywhere (flexible), no need for an additional cable connections, price affordable (economically), made from ingredients that are safe and harmless so it is safe for children, and can evoke the creativity of children especially older generation of millennial doctrines to develop another new thing more innovative and friendly the environment.

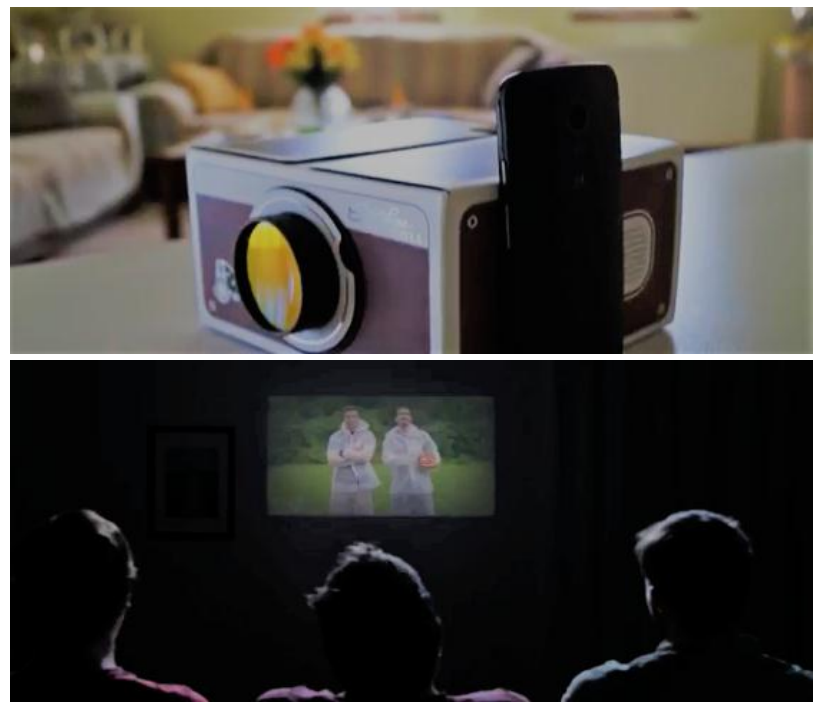

Figure 1. Mobile projector. 


\section{MATERIALS AND METHODS}

Research method in this research is research development. Research development of research method is used to produce a particular product and test the effectiveness of these products. The use of learning media will reproduce the learning experience of students, make students become bored, and provides an attractive learning to the students. Methods of teaching will be more varied, not merely verbal communication through the utterance of words by teachers, so students do not get tired of teaching and not run out of steam, especially if the teacher teaches at any hour lesson. Students may be doing more learning activities, for not only listening to descriptions of teachers, but also other activities such as observing, perform, demonstrate, playing, and others.

The research were located in a high school in Yogyakarta with the subjects of research of high school students. As for the product to be developed in this study is media of learning physics in innovative and environmentally friendly. The product used is a Mobile Projector. Mobile Projector is a simple imitation of the Projector in the form of a different and more innovative. This research was conducted at the State Islamic University Sunan Kalijaga Yogyakarta. Equipment and materials used in research namely cardboard shoes are made to resemble the Projector with the help of a magnifying glass (lup) to see clearer and larger than the size of the actual image or video. Also with the help of Rotation Control in mobile applications that can be downloaded at Play Store to set the rotation of the image or video when faced with a magnifying glass and formed a shadow rising, real and enlarged. It can provide a new alternative of Projector, ranging from the simple ingredients, easy to find, a sturdy shoe boxes and can be designed as you wish, you can take them everywhere (flexible), no need for an additional cable connections, price affordable (economically), made from ingredients that are safe and harmless so it is safe for children, and can evoke the creativity of children especially older generation of millennial doctrines to develop another new thing more innovative and friendly the environment.

\section{RESULTS AND DISCUSSION}

The development of technology and information is an inevitability and impossible it seemed if rejected or avoided especially in the current generation of millennial doctrines. Learning media is one of the educational technology which is very important. Learning through media can stir up new interest and desires, evoking motivation and stimulation of learning activities, even bringing psychology towards influences students (Rohman, 2013:161). However, the use of media of instruction is often overlooked, because there are still plenty of teachers who deliver the material with the lectures. This is not problematic when the material presented was indeed need not additional learning media or props are needed, but other things that make the children bored when teachers implement lectures on all material without any other inserts (which indeed needed) for students to understand the other things in the environment (be it practice or demonstration). This is a correction in a mencipkan atmosphere of different classes. Learning media each year continue to be developed by students, professors, or researchers. But the development of the learning media harvest problems. The problem happened, namely the lack of the use of media in price particularly learning-based android. This is due to several factors, namely because many schools sometimes do not allow carrying mobile phones to school. So the media is only used when the after-hours classes only.

Learning media innovation expected more formed when teachers using innovative learning so that media can be motivating and uplifting high of berkreatifitas students and hope the creation of a new innovation from the simplification of complex tools (consisting of various electronic components) into a simpler can be realized. Mobile Projector can be used as a substitute for a Projector in the classroom. This means another case with the learning media in android applications that sometimes needs the help of the internet access is relatively hard to come by in the village environment. This means aiming at improving the quality of education in Indonesia and a variety of educational institutions with emphasis on aspects of science and could also be applied in the community of the city or village.

\section{CONCLUSIONS}

Learning Media research already done by observing the learning achievements before and after using the media. On the research of Alamsyah Noerseelha with the title of "research learning media use power point" in SMK $\mathrm{N} 1$ learning achievements acquired Sumedang of 68.57 before using media and 80.00 after using media. With the name and title of the same study at JUNIOR HIGH SCHOOL N 1 Cimanggung obtained amounted to 61.90 before using media and 80.95 after using media and in JUNIOR HIGH SCHOOL N 1 Pamulihan of 67.74 before using media and 83.33 after using media. The main factors that can enhance the learning achievements and arouse the creativity of learners, namely the media and education. While the hallmark of a generation of millennial doctrines which tend to be deeply affected by the technology make it quickly bored with the monotonous thing. To address the authors offer solutions in the form of ideas where teachers use the media learning and learners practice to create a new media that he apply the learning of physics that they already get in College. 


\section{ACKNOWLEDGMENTS}

We thank God and parents who have helped us and the Faculty of science and technology who have been organizing this event.

\section{REFERENCES}

Bencsik, A., Csikos, G., \& Juhaz, T. (2016). Y and Z Generations at Workplaces. Journal of Competitiveness, 8(3), 90-106. Retrieved fromhttp://jurnal.stieama.ac.id/index.php/ama/article/ viewFile/142/133\&ved $=2$ ahUKEwjsqKux3tDdAhUJpI8KHaCG CrIQFjAAegQIAxAB\&usg=AOvVaw3Y3kgFxj9_Y_UXasjjHv9K

Fitri, P. Y., Astutik, S., \& Supriadi, B. (2018). Identification of Misconceptions of Newton's Laws in High School Students. National Seminar on Physics Education 2018, (pp. 19-22). (In Indonesian)

http://eprints.uny.ac.id/9432/12/12\%2520BAB\%2520II0850324700 4.pdf\&ved=2ahUKEwjLvcfL3NDdAhWJRo8KHY6xCYkQFjA AegQIBRAB\&usg=AOvVaw26oHjJ04pHqgFBs-2C9Vsl

Jurkiewicz, C. L. (2000). Generation X and the Public Employee. Public Personnel Management, 29 (1), 55. Retrivied from https://doi.org/10.1177/009102600002900105

Kilber, J., Barclay, A., and Ohmer, D. 2014. Seven Tips for Managing Generation Y. Journal of Management Policy and Practice. 15: 4, 80-9.
Lyons, S. (2004). An exploration of generational values in life and work. ProQuest Dissertations and Theses, 441-441. Retrieved fromhttp://ezproxy.um.edu.my/docview/305203456?accountid= 28930

Munadi, Yudhi. 2012. The Learning Media (A new approach). Jakarta: Echoes Of Persada (GP). Retrieved from https://jurnalmahasiswa.unesa.ac.id/index.php/jpak/article/view File/4098/6602\&ved $=2$ ahUKEwiT4dPD4NDdAhULLI8KHWB QDAgQFjABegQICBAB\&usg=AOvVaw25Z58TLJ7114aJNmRB $J P z 9$

Panjaitan, P., \& Prasetya, A. (2017). Social Media Influence on Millennial Generation Work Productivity. Journal of Business Administration Vol. 48 July 1, 173-180. (In Indonesian)

Rohman, Mohammad Sofan and Amri. (2013) Strategies and design Learning System development. Pustakaraya Feat. Jakarta. Retrieved from http://ejournal.upbatam.ac.id/index.php/ cbis/article/view /400/258

Samatowa, u. 2007. IPA learning in elementary school. Jakarta: Open University. Retrieved from Error! Hyperlink reference not valid.

Sudjana, Nana and Rivai, Ahmad. 2011. The teaching Media. Bandung: Some New. Light Algesindo. Retrieved from https://jurnalmahasiswa.unesa.ac.id/index.php/jpak/article/view File/4098/6602\&ved=2ahUKEwiT4dPD4NDdAhULLI8KHWB QDAgQFjABegQICBAB\&usg=AOvVaw25Z58TLJ7114aJNmRB $J P z 9$ 
THIS PAGE INTENTIONALLY LEFT BLANK 